position of a personal squabble, in which light $I$ am quite certain that you must be unwilling to have it intruded upon your readers. However, in justice to myself, I find it necessary to contradict, in the most absolute terms, several of their statements. First. It is not true that $I$ made any such statement to Mr. Prior as alleged by them. I never, either to that gentleman or to any other person, intimated my concurrence in their views with regard to the medical officers of the anion, or the line of conduct which in my judgment was proper to be pursued by the profession in the circumstances affecting the union. Secondly. They assert that my statement to the effect that $I$ resigned in 1844 because my assistants were not allowed to attend my cases is " nonsense," as $I$ at that time had none, but only one articled pupil. I repeat that $I$ had then two efficient assistants-viz., Messrs. Stephenson and Harrison, both of whom were perfectly able, from professional education and experience, to assist in medical and surgical practice, although not qualified. Thirdly. Messrs. Braddon and White state that "Mr. Braddon did not oppose Mr. Marsh when he might have done so with success," at the expiration of the probationary period of six months, for which I had been elected for the fourth district. To this I have to state that it is "nonsense" indeed, inasmuch as there was in reality no election at all. There was even no declaration of vacancy, the best proof of which is the fact that no advertisement appeared in the newspapers, as always is the case when an election takes place; and I was reappointed for twelve months, as a matter of course.

$I$ also repeat that $I$ am as sensible as any gentleman in the profession of the unworthy treatment too often experienced by its members who have the misfortune to be poor.law medical officers, of which I myself have been a devoted victim, though, on this occasion, I have been placed by circumstances in the position of opposing two gentlemen, who have at the eleventh hour, as it were, brought themselves prominently before the public as sticklers for the honour of the profession. I have not sought this position. Messrs. Braddon and White have in a very uncalled-for manner compelled me to repel a series of calumnious slanders, in venting which it appears to me that they have much less consulted the interest and honour of the profession than the gratification of private pique.-I remain, Sir, your obliged servant,

Henry B. Marsh, M.R.C.S. Eng. \& L.A.C.

Upton-on-Severn, Sept。19th, 1848.

\section{TRACHEOTOMY IN HYDROPHOBIA.}

To the Editor of THa Laxcer.

Sir,- Recourse to tracheotomy in hydrophobia was first proposed by Dr. Physick, of Philadelphia, in the New York Medical Repository, in 1802. The suggested use of tracheotomy was extended to other diseases by Dr. Marshall Hall, in his "Diseases of the Nervous System," published in 1841.

Mr. Turner's paper, to which he called your attention, p. 325, appeared, it seems, in The LANCET, in 1843 .

Sept. 15 th, 1848.

I am, Sir, your obedient servant,

\section{A MISREPRESENTATION EXPOSED. \\ To the Editor of THE LANCET.}

London and Provincial Medical Directory, 11, Beaufort-buildings, Strand, Sept. 20th, 1848.

SrR,-With reference to a lending article which appeared in The LaA CET of the 5th ultimo, indexed, "Gross Mal-practice in Midwifery; Trial at the Staffordshire Assizes," page 160 , in which the "London and Provincial Medical Direc. tory" is referred to as an authority regarding the professional qualifications of William Harding Flint, of Longnor, Staffordshire, we deem it our duty to send you a copy of the replies of Mr. W. H. Flint to our annual circular of the present year, as well as the correspondence to which recent circumstances have given rise.- We are, Sir, your obedient servants,

The Editors of the London and Provinctal Medical Directory.

\section{(Copy of Circular.)}

SIR,-The annexed specimen, taken from the "London Medical Directory" for 1846 , is respectfully submitted to your notice; it will be at the same time a guide as to the nature of the information we require, in conformity with the subjoined interrogatories, which we beg you to answer, in a clear and legible handwriting, and return by post at your very earliest convenience, not later than Saturday, October 31st.
You will please to observe, that gentlemen who do not make a return, and whose qualifications cannot be clearly identified, (frequently a very difficult matter,) will necessarily be entered in a supplemental list.

Your obedient servants,

The Editors.

Name and residence?-Willigm Harding Flint, Longnor, Staffordshire.

Whether practising as physician, surgeon, or general practitioner?-General practitioner.

Qualification, where obtained, and the date thereof?M.R.C.S., L.S.A., 22nd Dec. 1844.

If possessed of any medical appointment, now or formerly? -Medical officer, Bakewell Union.

W. H. Flint, Esq.

In reply to our inquiry as to the correctness of this return, we have received the following:-

The secretary to the Royal College of Surgeons acquaints the editors of the " Medical Directory," in reply to their inquiry, that Mr. William Harding Fiint, of Longnor, is not a member of the said college.

The secretary begs to observe that there are other individuals stated in the "Directory" for 1847 to be members of the college who are not members. 25th August, 1848.

Apothecaries' Hall, 26th August, 1848.

Sin,-In reply to your letter of the 24 th instant, I beg to inform you that no person of the name of William Harding Flint has received the certificate of the court of examiners of this Society,-I am, Sir, your most obedient servant,

To the Editors of the London and

Provincial Medical Directory.

Robt. B. Upton, Clerk to the Society.
Rents.

46, Princes-street, Soho, A ugust 29th, 1848.

Sir,-In consequence of recent events (to which twe have no desire further to allude) having called in question the accuracy of the "Medical Directory," as regards your qualifications as a practitioner, we have to request that you will either confirm or deny a return made to us (presumed by yourself) as a M.R.C.S. and L.S.A.; December 22nd, 1844, it being possible your qualifications may refer to some other societies than those of London, as, upon application to the College of Surgeons, and also to the Apothecaries' Company, we are assured that your name does not appear as a member of either of those societies. The character of the "Medical Directory" will be our apology for this intrusion, to which an explicit answer is necessary, with as little delay as possible, otherwise it will be our imperative duty to publicly vindicate the veracity of the work in question.- We are, \&c.,

W. H. Flint, Esq.

The Edrons.

Longnor, September 1st, 1848.

Gentiemen,-In answer to yours of the 29 th ultimo, I beg to say that, in making the return to you, I did so in what I considered a regular way, and according to the requirements of your application, following the example of several gentlemen known to me, whose names appear in the "Directory," and who, like myself, have derived their qualifications from lreland. "The entry, as it now stands in the "Directory," is virtually correct, with the exception of "Medical Officer Bakewell Union," which office was resigned in the month of April last.-I am, gentlemen, yours obediently,

W. H. FuIvT. London, 46, Princes-street, Soho,
September 4th, 1848 .

The editors of the "London and Provincial Medical Directory" present their compliments to the Registrar of the College of Surgeons, Dublin, and will feel obliged if he will take the trouble to examine the college list, and inform them if the name of William Harding Flint appears as a member thereof; and if so, the date of his diploma will be an additional favour.

Royal College of Surgeons in Ireland, September 6th, 1848.

The Registrar of the Royal College of Surgeons in Ireland presents his compliments to the editors of the "London and Provincial Medical Directory," and, in reply to their note of the $4 \mathrm{th}$ inst., begs to inform them that the name of William Harding Flint is not borne on the lists of this college, either as a fellow or licentiate.

London, 46, Princes-street, Soho, September 4th, 1848 .

The editors of the "London and Provincial Medical Directory" present their compliments to the Registrar of the 